\title{
Is high dose levetiracetam safe in the management of neonatal convulsion?
}

\section{Yenidoğan konvüllziyon tedavisinde yülksek doz levatirasetam güvenli mi?}

\author{
*Fatih Bolat ${ }^{1}$, Ahmet Sami Güven ${ }^{2}$, Meriç Kaymak Cihan ${ }^{3}$, Hikmet Çoskun ${ }^{3}$, Füsun \\ Dilara İçağasığ ${ }^{2}{ }^{2}$

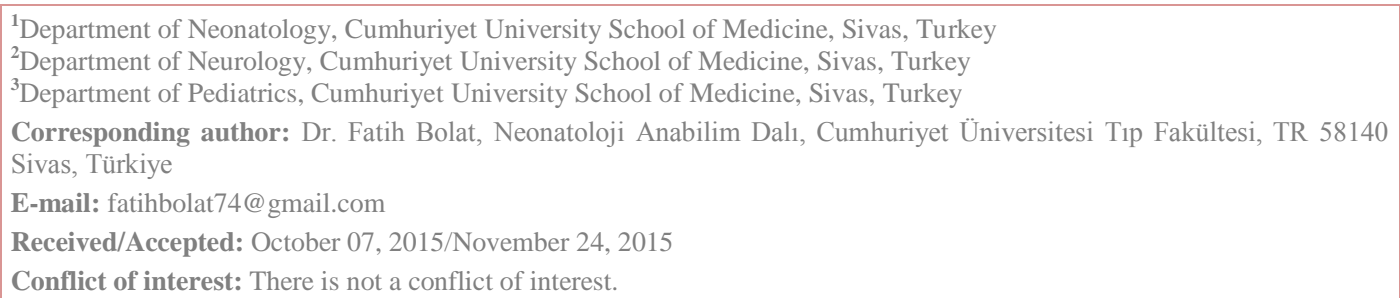

\section{SUMMARY}

Levetiracetam is a novel anticonvulsant drug that was approved by the FDA in adult and pediatric convulsions. There is not sufficient information regarding the use of newborn such as the appropriate dose and interval, its safety, efficacy and adverse effects. We present a case of a 10 day-old male, who was accidentally administered $75 \mathrm{mg} / \mathrm{kg} / \mathrm{d}$ levetiracetam for 3 days by his mother at home. The patient was discharged 4 days after admission to hospital without any signs and symptoms. The case demonstrated that high dose levetiracetam might be safe in newborn convulsions.

Keywords: Levetiracetam, newborn, convulsion, dose, safe

\section{ÖZET}

Levatirasetam erișkin ve pediatrik konvülziyonlarda FDA tarafından onaylanan yeni birantikonvülziyon ilaçtır. Yenidoğan kullanımı ile ilgili doz ve aralığı, güvenliği, etkinliği ve yan etkileri konusunda yeterli bilgi bulunmamaktadır. Annesi tarafından evde 3 gün boyunca kaza ile $75 \mathrm{mg} / \mathrm{kg} /$ gün levatirasetam verilen 10 günlük bir erkek bebek olguyu sunuyoruz. Hasta, hastaneye başvurduktan 4 gün sonra hiçbir bulgu ve semptom olmadan taburcu edildi. Bu olgu yüksek doz levatirasetam yenidoğan konvülziyonlarında kullanılabileceğini gösterdi.

Anahtar sözcükler: Levatirasetam, yenidoğan, konvülziyon, doz, güvenlik

\section{INTRODUCTION}

Seizures are more common during the neonatal period than any other time in life. The incidence varies depending on the underlying disease. The overall incidence is 1 to 4 per 1000 live births in term infants ${ }^{1}$. Although there is potential harm of seizures in the immature brain, there also is concern about possible adverse effects of anticonvulsant medications on the developing brain ${ }^{2}$.

Phenobarbital is the most frequently used medication to treat neonatal seizures ${ }^{3}$. However, animal and long-term human studies demonstrated that this drug could have deleterious effects such as cognitive dysfunction and learning impairment on the developing brain after treatment $t^{4,5}$.

Pharmacokinetic studies in adults indicate that levetiracetam has good bioavailability, rapid achievement of steady-state concentrations, less requirement for therapeutic drug monitoring, minimal protein binding compared to first generation antiepileptics $(<10 \%)^{6}$.

Case series suggest that levetiracetam may be a safe and effective for seizure treatment in all pediatric age groups ${ }^{7,8}$. In this 
case, our aim is to discuss whether high doses levetiracetam is safe in neonatal seizures.

\section{CASE REPORT}

A full term, $4050 \mathrm{~g}$, male infant was admitted to neonatal intensive care unit (NICU) with neonatal convulsion at postnatal 2 days. The infant was the first child of a 23 years old woman who did not have any perinatal problems. The parents were not consanguineous. In family history, his uncle was diagnosed as epilepsy at the age 2.5 years. The patient was born via cesarean section due to cephalopelvic disproportion. Apgar score was 8 and 9 at 1st and 5 th minutes, respectively. Cord blood gases were normal. On the second day of life, myoclonic jerks were noted on physical examination. The vital signs were noted as: axillary temperature $37.1 \mathrm{oC}$, heart rate $148 / \mathrm{min}$., respiratory rate $60 / \mathrm{min}$., saturation on pulse oximetry $94 \%$ in room air and blood pressure $60 / 35 \mathrm{mmHg}$. His birth weight was $4150 \mathrm{~g}$ (>97th centile), birth length was $51 \mathrm{~cm}$ (50th-75th centile) and head circumference was $36 \mathrm{~cm}$ (50th centile). Physical examination did not show any other abnormal findings.

Arterial blood gas analysis in room air revealed a pH: $7.45, \mathrm{pCO}_{2}: 35 \mathrm{mmHg}$, $\mathrm{pO}_{2}: 78 \mathrm{mmHg}, \mathrm{HCO}_{3}: 22 \mathrm{mEq} / \mathrm{L}$ and base deficit: -4.5. The laboratory studies showed the following results: hemoglobin $17.7 \mathrm{~g} / \mathrm{dL}$, hematocrit 54\%, leukocyte count $16800 / \mathrm{mm}^{3}$ (68\% neutrophils, $32 \%$ lymphocytes), platelet count $524000 / \mathrm{mm}^{3}$, C-reactive protein $2.31 \mathrm{mg} / \mathrm{L}$ and blood glucose $96 \mathrm{mg} / \mathrm{dL}$. Other biochemical stud- ies were within normal limits. Computed tomography of the brain, echocardiography, metabolic studies, and neurosonography were also normal.

On the day of admission, he had 6 seizures characterized by focal myoclonic jerks lasting from 1 minute to five minutes. Levetiracetam was initiated orally at 20 $\mathrm{mg} / \mathrm{kg} / \mathrm{day}$. The patient's clinical status improved and no additional seizures were noted. Electroencephalogram (EEG) demonstrated focal epileptic activity with isolated sharp slow-wave discharges at the centrotemporal areas of right hemisphere that were clinically accompanied by focal myoclonic jerks (Figure 1a). He was discharged from the hospital in a good clinical condition at one week old. After the discharge from the NICU, he was administered $75 \mathrm{mg} / \mathrm{kg} /$ day levetiracetam for 3 days by his mother at home. Patient was hospitalized again due to pre-diagnosis of LV intoxication. The National Poison Center was contacted by telephone. Close monitoring of the patient for up to 24 hours recommended because of the risk of respiratory and central nervous system depression. Meanwhile, EEG was normal for conceptional age (Figure 1b). Serum concentration of levetiracetam was measured by using a validated gas chromatography technique and levetiracetam level was 30.1 $\mathrm{mg} / \mathrm{dL}$ (Normal level: $5-45 \mathrm{mg} / \mathrm{dL}$ ). $\mathrm{He}$ was discharged 4 days after admission to hospital without any signs and symptoms. The baby has being followed up regularly in pediatric neurology department and he has normal neurologic development according to his age. 


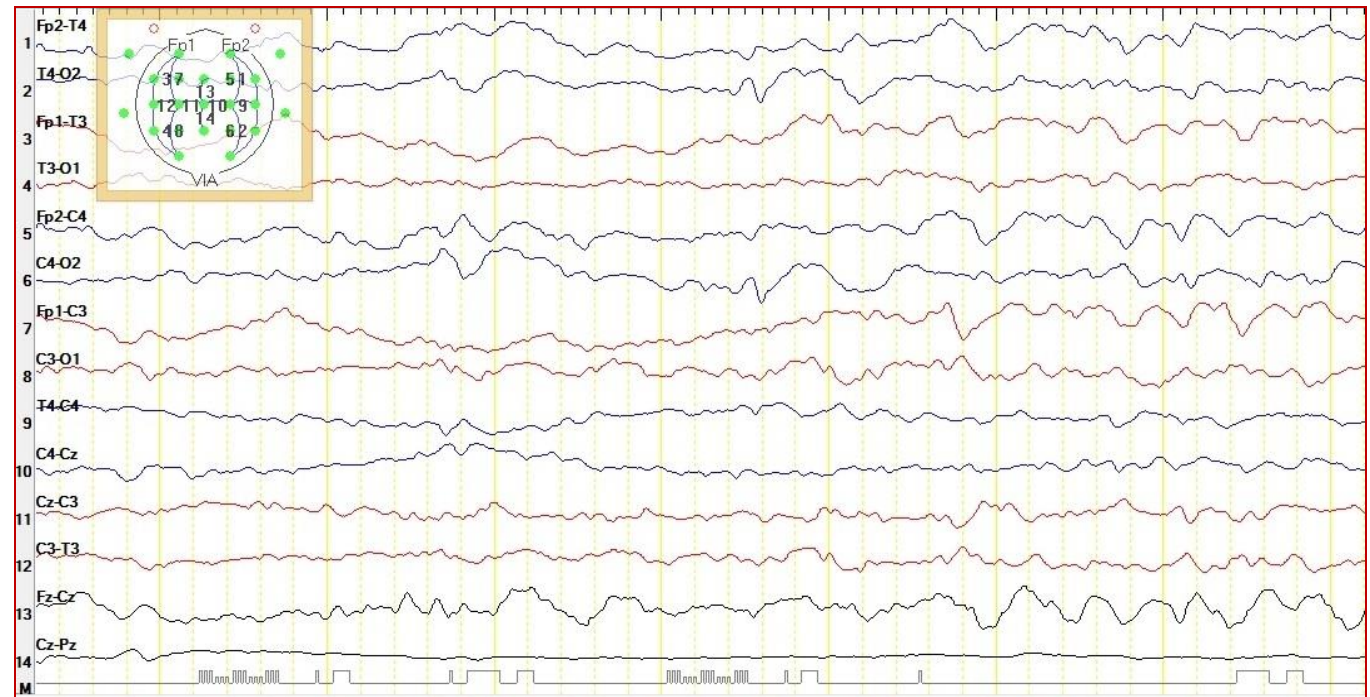

Figure 1a: EEG before levetiracetam treatment.

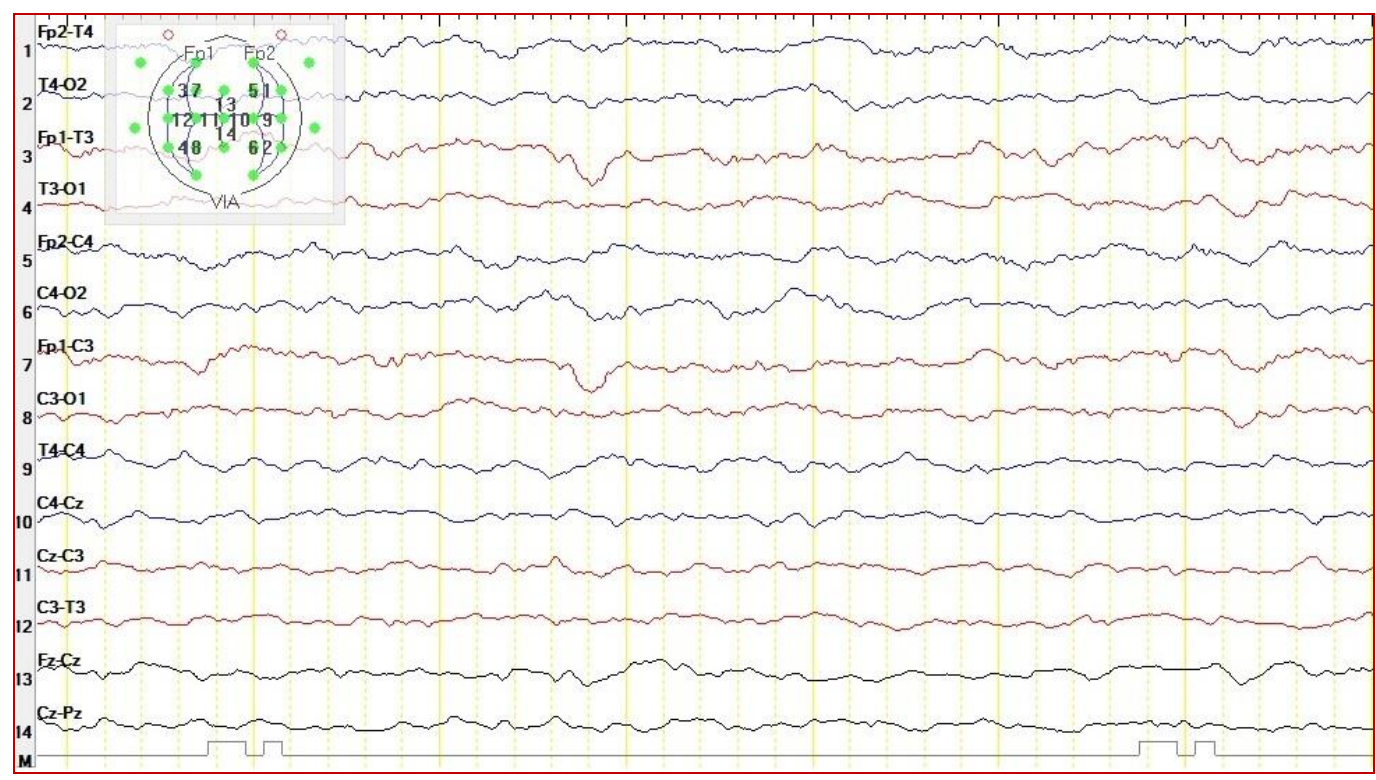

Figure 1b: EEG after levetiracetam intoxication.

\section{DISCUSSION}

Neonatologists are more familiar with neonatal convulsions but the question of which drug should be chosen for its treatment has not been answered. Sufficient information about second-generation anticonvulsants like levetiracetam, especially newborns was not uniformly reported in the previously published studies. Our data suggests that high dose levetiracetam (75 $\mathrm{mg} / \mathrm{kg} / \mathrm{dL}$ ) can be used safely without any side effects in neonatal seizure. Despite the widespread use of levetiracetam, there is no consensus on dosage. The drug has generally been used as an initial dosage of
$5-10 \mathrm{mg} / \mathrm{kg}$ per dose every 12 hours intravenous or orally in neonatal period ${ }^{9}$. The dosage was increased every week up to a maximum $60 \mathrm{mg} / \mathrm{kg}$ per day ${ }^{10}$. Serum concentrations are not routinely monitored, although they may be useful in determining the magnitude of dosing adjustments. Therapeutic concentrations are approximately 10 to $40 \mathrm{mcg} / \mathrm{mL}^{11}$.

The renal clearance of levetiracetam is very rapid with a value of $0.6 \mathrm{~mL} / \mathrm{kg} / \mathrm{min}$. Its plasma half-life in health subject is approximately 6-8 hours (h). Levetiracetam's half-life and apparent clearances are dose independent. It is considered that 
levetiracetam has low affinity for plasma protein binding as the volume distribution is close to the volume of total body wa$\operatorname{ter}^{12}$. In our case, despite the use of high doses of levetiracetam, serum level was within normal limits. Normal serum levels after high doses of levetiracetam may be due to high metabolic rate, tolerability during dosing and to the distribution of increased total body water in neonates.

Levetiracetam shows a favorable pharmacokinetic profile in the pediatric population and has also been recommended for treatment of neonatal convulsion ${ }^{13}$. The case reported by Tanriverdi et al. ${ }^{14}$. Demonstrated that levetiracetam was effective in other antiepileptic-resistant neonatal status epilepticus. Although off-label use of intravenous and oral levetiracetam formulation for neonatal seizures is very common, the efficacy and safety have not been evaluated extensively in neonates. The drug is well absorbed after oral administration and peak concentration within 2 hours. Bioavailability is not affected by foods. The drug is excreted mainly in the urine. Dose should be adjusted in patients with renal impairment. There are few drug interactions. In a study by Merhar et al. ${ }^{15}$ in 18 neonatal seizures, levetiracetam were found to have lower clearance, higher volume of distribution, and a longer half-life compared with older children and adults. The plasma half-life of levetiracetam in newborns is longer $(8.9 \mathrm{~h})$ than in older children (5-7 h). Signs and symptoms of levetiracetam toxicity include somnolence, behavioral problems anxiety, depression, emotional instability and headache. These effects are commonly observed in adult patients, in whom anticonvulsant therapy other than levetiracetam are used. In the use of levetiracetam, such side effects have rarely been reported in childhood ${ }^{16,17} . \mathrm{Cu}-$ taneous reactions caused by antiepileptic drugs have a wide range of clinical features, from mild cutaneous erythematous rash to life-threatening Stevens-Johnson syndrome or toxic epidermal necrolysis ${ }^{18}$. Although the lesions are observed in $15 \%$ of patients treated with first generation antiepileptic drugs, with a second generation antiepileptic drug like levetiracetam have been rarely reported ${ }^{19}$. Recently,
Koklu et al. $^{20}$ reported intravenous levetiracetam-induced anaphylaxis in a newborn. Our patient was closely monitored for 48 hours for signs and symptoms of levetiracetam intoxication. No clinical side effects were observed.

Although the use of high dose levetiracetam has rarely documented in neonatal seizures, we did not reveal any clinical side effect compared with prior studies. Moreover, the serum level was also normal. It seems that high dose levetiracetam may be safely used in newborn convulsion; however further pharmacokinetic and clinical studies are needed to prove this assumption.

\section{REFERENCES}

1. Van Rooij LG, Hellstrom-Westas L, de Vries LS. Treatment of neonatal seizures. Semin Fetal Neonatal Med 2013; 18: 209-15.

2. Glass HC, Kan J, Bonifacio SL, Ferriero DM. Neonatal seizures. Treatment practices among term and preterm infants. Pediatr Neurol 2012; 46: 111-5.

3. Bartha AI, Shen J, Katz KH, Mischel RE, Yap KR, Ivacko JA, Andrews EM, Ferriero DM, Ment LR, Silverstein FS. Neonatal seizures: Multicenter variability in current treatment practices. Pediatr Neurol 2007; 37: 85-90.

4. Diaz J, Schain RJ, Bailey BG. Phenobarbital-induced brain growth retardation in artificially reared rat pups. Biol Neonate 1977; 32: 77-82.

5. Sulzbacher S, Farwell JR, Temkin N, Lu AS, Hirtz DG. Late cognitive effects of early treatment with phenobarbital. Clin Pediatr (Phila) 1999; 38: 387-94.

6. Patsalos PN. Pharmacokinetic profile of levetiracetam: Toward ideal characteristics. Pharmacol Ther 2000; 85: 77-85.

7. Silverstein FS, Ferriero DM. Offlabel use of antiepileptic drugs for the treatment of neonatal seizures. Pediatr Neurol 2008; 39: 77-9.

8. Ramantani G, Ikonomidou C, Walter B, Rating D, Dinger J. Le- 
vetiracetam: Safety and efficacy in neonatal seizures. Eur J Paediatr Neurol 2011; 15: 1-7.

9. Grosso S, Cordelli DM, Franzoni E, Coppola G, Capovilla G, Zamponi N, Verrotti A, Morgese G, Balestri P. Efficacy and safety of levetiracetam in infants and young children with refractory epilepsy. Seizure 2007; 16: 345-50.

10. Striano P, Coppola A, Pezzella M, Ciampa C, Specchio N, Ragona F, Mancardi MM, Gennaro E, Beccaria $\mathrm{F}$, Capovilla $\mathrm{G}$, Rasmini $\mathrm{P}$, Besana D, Coppola GG, Elia M, Granata T, Vecchi M, Vigevano F, Viri M, Gaggero R, Striano S, Zara F. An open-label trial of levetiracetam in severe myoclonic epilepsy of infancy. Neurology 2007; 69: 250-54.

11. Reuters T (ed Neofax 2011. ed., Thomson Reuters, 2011.

12. Petruševska M, Berglez S, Krisch I, Legen I, Megušar K, Peternel L, Abrahamsson B, Cristofoletti R, Groot DW, Kopp S, Langguth P, Mehta M, Polli JE, Shah VP, Dressman J.Biowaiver Monographs for Immediate Release Solid Oral Dosage Forms: Levetiracetam. J Pharm Sci 2015; 104: 267687.

13. Beaulieu MJ. Levetiracetam. Neonatal Netw 2013; 32: 285-8.

14. Tanriverdi S, Terek D, Koroglu OA, Yalaz M, Tekgul H, Kultursay N. Neonatal status epilepticus controlled with levetiracetam at sturge weber syndrome. Brain Dev 2013; 35: 367-71.

15. Merhar SL, Schibler KR, Sherwin CM, Meinzen-Derr J, Shi J, Balmakund T, Vinks AA. Pharmacokinetics of levetiracetam in neonates with seizures. J Pediatr 2011; 159: $152-4$.

16. Wheless JW, Ng YT. Levetiracetam in refractory pediatric epilepsy. J Child Neurol 2002; 17: 4135.

17. Lagae L, Buyse G, Ceulemans B. Clinical experience with levetiracetam in childhood epilepsy. An add-on and mono-therapy trial.
Seizure 2005; 14:66-71.

18. Zou LP, Ding CH, Song ZJ, Li XF. Stevens-Johnson syndrome induced by levetiracetam. Seizure 2012; 21: 823-5.

19. Blaszczyk B, Szpringer M, Czuczwar SJ, Lason W: Single centre 20 year survey of antiepileptic drug-induced hypersensitivity reactions. Pharmacol Rep 2013; 65: 399-409.

20. Koklu E, Ariguloglu EA, Koklu S: Levetiracetam-induced anaphylaxis in a neonate. Pediatr Neurol 2014; 50: 192-4. 